\title{
Relationships between Transformational and Active Transactional Leadership and Followers' Organizational Identification: The Role of Psychological Empowerment
}

\author{
Weichun Zhu \\ Department of Labor Studies and Employment Relations \\ College of Liberal Arts \\ The Pennsylvania State University \\ University Park, PA 16802 \\ Phone: (814) 865-9116 \\ Email:wzhu@psu.edu \\ John J. Sosik \\ School of Graduate Professional Studies at Great Valley \\ The Pennsylvania State University \\ 30 East Swedesford Road \\ Malvern, PA 19355 \\ Phone: (610) 648-3254 \\ Email: jjs20@psu.edu \\ Ronald E. Riggio \\ Kravis Leadership Institute \\ Claremont McKenna College \\ Claremont, CA 91711 \\ Phone: (909) 607-2997 \\ Email: ron.riggio@cmc.edu \\ Baiyin Yang \\ Department of Human Resources and Organizational Behavior \\ School of Economics and Management \\ Tsinghua University \\ Beijing, China 100084 \\ Phone: 86-10-6279-6314 \\ Email: yangby@sem.tsinghua.edu.cn
}

\begin{abstract}
We examined the underlying processes through which transformational and active transactional leadership affects followers' organizational identification in a survey study. Using a sample of managers across different industries, we found that followers' psychological empowerment, including competence, impact, meaning, and selfdetermination, partially mediated the effect of transformational leadership and active transactional leadership on followers' organizational identification. Furthermore,
\end{abstract}


transformational leadership explained variance in followers' organizational identification and psychological empowerment above and beyond active transactional leadership. These findings provide additional support for transformational leadership theory by demonstrating a motivational mechanism through which followers identify with their organizations. Theoretical contributions and practical implications are discussed.

Keywords: transformational leadership, active transactional leadership, organizational identification, psychological empowerment

\section{Introduction}

Transformational leadership has been a topic of much research in the past three decades. There has been accumulating evidence to suggest that transformational leadership has a positive effect on follower work attitudes and performance at both the individual and organizational levels (e.g., Lowe, Kroeck, \& Sivasubramaniam, 1996). However, it appears that more attention needs to be given to the investigation of the underlying mechanisms and processes by which transformational leaders exert their influence on followers, and ultimately their performance (Kark \& Shamir, 2002). Some leadership researchers (e.g., Shamir, House, \& Arthur, 1993; Yukl, 2010) consistently emphasize that different transformational leader behaviors might involve different influence processes.

Shamir et al. (1993) proposed a self-concept-based theoretical model to explain the motivational effects of charismatic/transformational leadership on followers. According to this theory, charismatic/transformational leaders influence followers in the following three ways: by increasing followers' self-efficacy, by influencing followers' value internalization, and by facilitating followers' social identification with the group. Kark, Shamir, and Chen (2003) further proposed that follower social identification mediates the effect of charismatic/ transformational leadership on important follower psychological states, such as organizational-based self-esteem and collective efficacy. However, they did not clearly explain the underlying processes through which charismatic/transformational leadership affects follower social identification, and this is a gap in the literature that we aspire to fill in this study. Nor did they contrast these effects against those of transactional leadership, an exchanged-based leadership style also associated with positive outcomes (Bass, 1985: Sosik \& Jung, 2010). Therefore, we proposed and tested in this study the theoretical model shown in Figure 1 as an extension and alternative to the theoretical model proposed by Kark et al. (2003).

Accordingly, the main purpose of this study is to draw upon perspectives from transformational leadership theory (Bass, 1985), the self-concept-based motivational explanations of charismatic/transformational leadership (Kark et al., 2003; Shamir et al., 1993), organizational identification theory (Ashforth, Harrison, \& Corley, 2008; Tajfel, 1972), and psychological empowerment theory (Spreitzer, 1995) to develop and test a theoretical model which casts light on the underlying processes by which 


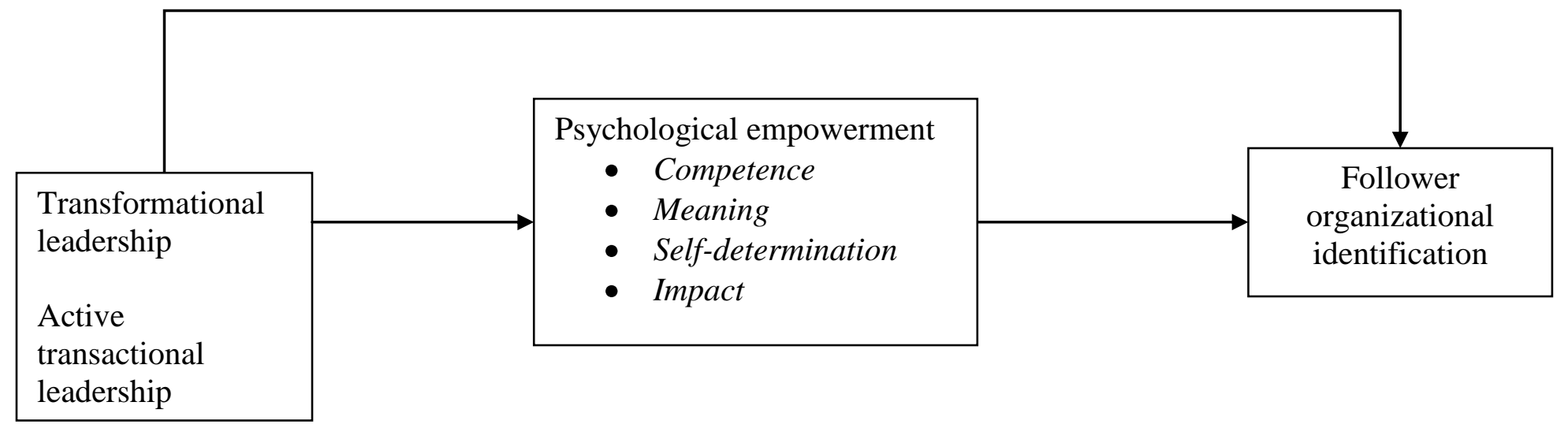

Figure 1. Theoretical Model of the Relationship between Transactional/Transformational Leadership, Follower Psychological Empowerment, and Organizational Identification 
transformational leaders influence followers' organizational identification via enhancing followers' psychological empowerment.

\section{Theoretical Framework and Hypotheses Development}

Ashforth et al.'s (2008) model of narrow and broad formulations of organizational identification serves as the theoretical framework for our study. Briefly, this model proposes that organizational identification is a function of one's self-definition, importance, and affect, which provide the core of identification. Also, the content of identification is proposed to stem from one's values, goals, beliefs, traits, knowledge, skills, and abilities. The core and content of identification are proposed to influence behaviors reflecting one's identity.

According to transformational leadership theory (e.g., Bass, 1985) and self-conceptbased explanations of such leadership (Shamir et al., 1993; Sosik \& Cameron, 2010), transformational leaders influence followers' self-definitions, affect, values, beliefs, and behaviors. They also empower followers to recognize the importance of their work and develop their knowledge, skills and abilities to reach their full potential (Bass, 1985). Thus, transformational leaders are likely to be associated with empowered followers who possess strong identification with their organizations.

In this section, we will first define the primary constructs in our theoretical model, including transformational and active transactional leadership, organizational identification, and psychological empowerment. Secondly, based on transformational leadership theory (Bass, 1985) and organization identification theory (Ashforth et al., 2008), we explain how transformational and active transactional leadership affect follower organizational identification. Furthermore, utilizing psychological empowerment theory (Spreitzer, 1995) and organizational identification theory (Ashforth et al., 2008), we explain how psychological empowerment works as an important mediation mechanism through which transformational and active transactional leadership affects follower organizational identification. We then explain why transformational leadership is expected to explain variance in followers' psychological empowerment and organizational identification above and beyond active transactional leadership.

\section{$\underline{\text { Transformational Leadership }}$}

Transformational leadership was proposed by Burns (1978) and further expanded upon by Bass and others (e.g., Bass, 1985; Bass \& Avolio, 1997; Bass \& Riggio, 2006; Sosik \& Jung, 2010). Transformational leadership contains four components: Charisma or Idealized Influence (attributed or behavioral), Inspirational Motivation, Intellectual Stimulation, and Individualized Consideration. Transformational leaders who display idealized influence set high standards for moral and ethical conduct, are confident about the future, and set high standards for emulation. Inspirational motivation involves transformational leaders providing followers with challenges and meaning for engaging in shared goals and undertakings. With intellectual stimulation, transformational leaders challenge their followers to be creative and innovative, to question long-term 
assumptions, to reframe questions, and to use new methods and mindsets to solve traditional problems and questions. Transformational leaders also display individualized consideration by paying special attention to specific followers' needs for personal growth and achievement, and trying to meet their needs and satisfy their expectations for future development (Bass, 1985). Transformational leadership has been shown to add to the effectiveness of transactional leadership on followers' attitudes and performance outcomes, thus demonstrating what is called the "augmentation effect" (cf. Bass, 2008; Yukl, 2010).

\section{Psychological Empowerment}

Spreitzer (1995, p. 1443) defined psychological empowerment as "increased intrinsic task motivation manifested in a set of four cognitions reflecting an individual's orientation to his or her work role: meaning, competence, self-determination and impact." An individual experiences meaning when he/she believes that work is meaningful and is given greater responsibilities. Competence refers to an individual's feelings of self-efficacy or personal mastery that he/she can successfully accomplish a task. Self-determination refers to an individual having the freedom to perform his/her tasks in the way that one chooses (Fulford \& Enz, 1995). Self-determination shows one's feelings of autonomy in making decisions in areas such as work methods, time, pace, and effort (Spreitzer, 1995). Finally, impact refers to the degree to which an individual believes that his/her work makes a significant difference in achieving the purpose of the task, and the extent to which the individual believes that he or she can influence organizational outcomes (Spreitzer, 1995).

\section{Organizational Identification}

Tajfel (1972, p. 272) defined social identity as "the individual's knowledge that he belongs to certain social groups together with some emotional and value significance to him of his group membership." Tajfel argued that social identity is knowledge of being a group member and thus of what attributes define membership in the group, but social identity also involves an emotional attachment to the group. Social identity is a theory of the self. Tajfel and Turner (1979) proposed that social identity rests on a fundamental distinction between social identity, which is related to group membership, and personal identity, which is related to personal relationships and idiosyncratic attributes.

Organizational identification is concerned with an organizational member's perception of "oneness" with an organization (Ashforth \& Mael, 1989). Based on social identity theory, organizational identification has a positive effect on followers' supportive behaviors for realizing organizational objectives and goals (Hekman, Steensma, Bigley, \& Hereford, 2009); therefore it is important for leaders to develop followers' organizational identification.

Organizational identification includes cognitive and emotional components. The cognitive component demonstrates the common interests an individual perceives that he/she shares with the organization (Ashforth \& Male, 1989) and the calculative benefits 
that he/she can gain through associating with the organization. It also indicates the degree to which a person identifies him/herself as a member of the organization, while the emotional component reflects an individual's feelings of pride in being a member of an organization. The emotional component of organizational identification plays an important role in creating an individual's positive image of one's organization, and helps to develop identification with the organization (Tajfel, 1972). Pratt (1998) proposed that an individual has two main and basic motives for identification with an organization. The first motive lies in the need for self-categorization, which helps an individual to seek a unique place and feel different from other members of the organization or society. The second motive develops from a need for self-enhancement and self-esteem, which means that an individual aspires to be rewarded and feel pride through association with or membership in an organization.

Organizational identification appears to be distinct from organizational commitment. Specifically, organizational identification concerns an individual's self-perception on how he/she perceives being one with the organization which implies the self being the focal referent, whereas organizational commitment concerns one's general attitude toward the organization and its members and focuses on one's relationship with these referents (van Knippenberg \& Sleebos, 2006). Organizational commitment contains affective, continuance, and normative components (Meyer \& Allen, 1991), and meta-analytic work conducted by Riketta (2005) indicates an empirical overlap between organizational identification and affective organizational commitment. However, Riketta (2005) concluded that these constructs can be distinguished because they are conceptually different and lead to different organizational outcomes, such as organizational identification having a larger negative correlation with intent to leave than affective organizational commitment.

\section{Transformational Leadership, Active Transactional Leadership, and Followers'} Organizational Identification

An important construct for understanding the impact of transformational leadership is social identity. Kark and Shamir (2002) proposed that transformational leaders influence two distinct levels of their followers' self-concept: the relational and the collective self. Followers come to identify with their particular leader through the relational aspects of the followers' self-concept, while organizational or social identification is influenced by priming of their collective self. Transformational leaders emphasize organizational justice, so followers are more likely to identify with their leader and organization. Shamir, Zakay, Breinin, and Popper (1998) proposed that transformational leaders could emphasize followers' contribution to membership or group, and then shift followers' identification from the individual level to the collective level.

Furthermore, leaders can create group level influences, including collective identification, by establishing symbolic activities, which will increase follower self esteem and consequently lead to organizational identification (Shamir et al., 1993). Transformational leaders create a supportive work environment that emphasizes employees' needs and feelings, develops new skills, and helps solve various job 
problems and other challenges. In addition, transformational leaders offer constructive and positive suggestions to employees, which can help improve followers' positive feelings of being a member in an organization, and increase their identification with the organization.

Transformational leaders try to develop followers' full potential (e.g., Bass, 1985; Johnson \& Dipboye, 2008); therefore, followers may tend to feel that their organization is effective and that it can provide future opportunity and development. As such, it is expected that followers will be more likely to stay in the organization because they are satisfying their needs for self-categorization/self-identity, and they have a sense of being unique from other members in society. Organizational identification is therefore likely to be strengthened. Thus,

Hypothesis 1: Transformational leadership has a positive relationship with followers' organizational identification.

Theoretically speaking, as widely known, Bass and his colleagues (e.g., Avolio, 1999; Bass \& Riggio, 2006; Sosik \& Jung, 2010) categorized full range leadership into transactional and transformational leadership behaviors. Transactional leadership behaviors include: passive management by exception (MBEP), active management by exception (MBEA), and contingent reward (CR). Transformational leadership behaviors include inspirational motivation, idealized influence, intellectual stimulation, and individualized consideration. Among three types of transactional leadership behaviors, passive management by exception (MBEP) is considered to be a passive transactional leadership behavior, while active management by exception (MBEA) and contingent reward leadership behaviors are considered "active" transactional leadership, as demonstrated empirically in a number of studies (e.g., Avolio, Bass, Walumbwa, \& Zhu, 2004; Bycio, Hackett, \& Allen, 1995; Zhu, Riggio, Avolio, \& Sosik, 2011).

In addition to displaying transformational leadership behaviors, effective leaders also display active transactional leadership comprised of contingent reward and active management-by-exception behaviors (Bass, 1985). With contingent reward, transactional leaders define and communicate what needs to be done, how it will be done, and the rewards and recognition followers will receive if the assignments are done satisfactorily. Another component of active transactional leadership is active management-by-exception behavior, in which the leader specifies the standards for compliance, as well as what constitutes ineffective performance, and may punish followers for being out of compliance with those standards. The leader arranges to actively monitor deviances, mistakes, and errors in the followers' assignments and to take corrective action as necessary. Through the active form of management-byexception, transactional leaders monitor follower performance and take necessary corrective actions to force followers to change their work attitudes and behaviors (Sosik \& Jung, 2010). The main focus of both forms of management-by-exception is on setting standards and monitoring deviations from the specified standards. Therefore, the leaders and followers find the exchange mutually rewarding, and contribute to developing this positive relationship, which is expected to contribute to followers' 
identification with the organization. As a result, one's organizational identification is likely to be enhanced.

This line of reasoning is supported by prior empirical and theoretical work. Specifically, Epitropaki and Martin (2005) proposed that transactional leadership promotes followers' organizational identification by triggering followers' self-categorization processes (Turner, 1972). When leaders provide contingent rewards and monitor followers' performance for errors and deviations, they clarify followers' expectations regarding norms and values. Such clarification allows followers to better understand their organizational roles and the consistency between their personal values and the organization's values regarding goals and performance expectations, thereby promoting their identification with the organization. In a study of Greek bank employees, Epitropaki and Martin (2005) reported a significant positive relationship between these employees' perceptions of their leaders' display of transactional leadership and their organizational identification. Thus,

Hypothesis 2: Active transactional leadership has a positive relationship with followers' organizational identification.

\section{The Mediating Role of Psychological Empowerment}

As previously mentioned, the process by which leadership influences followers' organizational identification has been under-researched. We propose that psychological empowerment is an important mechanism through which leaders can influence followers' organizational identification. Leadership and supervision serve as one of the most important mechanisms to develop followers' personal efficacy and feelings of power (Koberg, Boss, Senjem, \& Goodman, 1999).

Yukl (2010) proposed that leadership can enable the process of building commitment to the organization's objectives and can empower followers to accomplish these objectives. Followers who feel more empowered tend to reciprocate by being more committed to their organization (e.g., Koberg et al., 1999; Wang \& Lee, 2009), which suggests that followers may be more likely to identify with their organization, given the conceptual and empirical similarities between organizational identification and affective organizational commitment (Riketta, 2005).

Several empirical studies (e.g., Avolio, Zhu, Koh, \& Bhatia, 2004; Fuller, Morrison, Jones, Bridger, \& Brown, 1999; Kark et al., 2003) have demonstrated a positive relationship between transformational leadership and followers' psychological empowerment. The authors of these studies highlighted transformational leadership's role of creating more social identification with the group or organization in making followers feel more empowered. Some researchers (e.g., Bass, 1985; Sosik \& Jung, 2010) proposed that transformational leaders have a clear and meaningful vision for their organization and direct their organization toward that goal. This vision is often powerful and portrays a much-improved company and/or a better way of operating the business. Transformational leaders create a strategic and innovative vision that is 
compelling, and they then communicate that vision to all employees so that they too will believe in it and will become excited by it. Thus, employees are more likely to believe that their work is important and their organization has a better and more meaningful future. Given that employees are "meaning-seekers" and the process of social identification with collectives helps reduce uncertainty (Ashford et al., 2008), a meaningful vision may satisfy their needs for competence, self-determination, and impact by being a member of an effective organization. Thus, followers' psychological empowerment and identification with the organization would be more likely to increase.

Transformational leaders possess great referent and inspirational power (Bass, 1985) which enables them to gain the respect, admiration, and trust of their followers. They are also seen as role models who exert significant and positive influence on followers that creates a sense of meaningfulness (Bass, 1985). Employees who experience a greater sense of meaning from their work are likely to feel more empowered (Spreitzer, 1995) and proud of being a member of the organization, and thereby enhance their identification with the organization (Koberg et al., 1999). Numerous researchers (e.g., McCann, Langford, \& Rawlings, 2006; Shamir et al., 1993; Sosik \& Cameron, 2010; Sosik \& Jung, 2010) have argued that transformational leaders get followers involved in envisioning an attractive future and can also inspire the followers to identify with the vision through social identification processes. Transformational leaders align followers' self-identities with their organization's values and mission (Shamir et al., 1993). According to social identity theory (Tajfel \& Turner, 1972), individuals seek consistency between their self-identity and the values associated with their organization. When individuals perceive consistency between their self-identity and the actions required to support their organization's values and mission, they are more likely to engage in activities that are consistent with their self-identity and identify with the organization because it embodies their self-construals (Tajfel, 1972).

Transformational leaders' enthusiasm and optimism can build team spirit and can also provide meaning and challenge to followers' work or tasks, enhancing followers' feelings of impact, competence, meaning, and autonomy associated with psychological empowerment. All these factors can contribute to organization members' feeling pride from being a part of their organization, which consequently increases their identification with the organization (Ashford et al., 2008).

Transformational leaders also show individualized consideration, such as listening attentively and paying close attention to their followers' needs for achievement and growth. Such behaviors encourage followers to take on increasingly more responsibilities in order to develop to their full potential (Bass, 1985), thereby increasing their perceived competence associated with psychological empowerment (Spreitzer, 1995). Furthermore, transformational leaders provide followers with greater opportunities for decision latitude, challenge, and responsibility, which will cause followers to feel more confident and meaningful, and therefore psychologically empowered. This helps to satisfy followers' need for affiliation within the organization by improving their self-esteem, which eventually may enhance their identification with the organization (Ashford et al., 2008). 
Hypothesis 3: Psychological empowerment mediates the relationship between transformational leadership and followers' organizational identification.

Likewise, the effect of active transactional leadership on followers' organizational identification is likely to be mediated by followers' psychological empowerment. Gkorezis and Petridou (2008) proposed that three elements of active transactional leadership, namely information feedback, recognition, and financial rewards, are positively related to followers' psychological empowerment. As such, both contingent reward and active management-by-exception leadership provides information such as goals and positive and negative feedback to followers (Bass, 1985), and thereby may allow followers to better assess their competence and the impact they are making in influencing organizational outcomes. Competence and impact are essential elements of psychological empowerment (Spreitzer, 1995).

Contingent reward behavior, in the forms of defining what needs to be done, how to get things done, and what performances need to be achieved, may enable followers to be psychologically empowered by better understanding the significance, meaning, and value of their job (Epitropaki \& Martin, 2005; Spreitzer, 2005). Through active management-by-exception, followers are able to realize what behaviors and performances are considered deviances, mistakes, and errors in the assignments and to take corrective action to respond accordingly (Sosik \& Jung, 2010), thereby clarifying role expectations required for organizational identification (Epitropaki \& Martin, 2005). Along the way, followers are likely to consider these active transactional leadership behaviors as positive feedback, which may make them feel more empowered.

As a result of the transformational leader's focus on developing followers into leaders and of active transactional leaders' positive exchange relationships, followers are likely to feel that their roles are worthwhile and meaningful, thus raising their level of selfesteem, which, in turn, increases follower identification with the organization (Ashford et al., 2008). Furthermore, since empowered followers have a sense of psychological selfworth and meaningfulness, they are likely to be proud members of the organization and have stronger identification with their organization (Wang \& Lee, 2009).

Ashford et al. (2008) point out that there is empirical support for relationships between the meaning individuals find in their work and their organizational identification. For example, in an empirical study of blue-collar workers in the shipping industry, Erturk (2010) reported a positive relationship between psychological empowerment and organizational identification. Similarly, prior research has demonstrated a positive association between psychological empowerment and affective organizational commitment for nurses in hospitals (Avolio et al., 2004) and for employees and their supervisors (Liden, Wayne, \& Sparrow, 2000). These authors used social identity theory (Tajfel, 1972) to explain how empowered workers' self-construals of competence, autonomy, purposeful work, and impact make them identify with their organization as a place where they can achieve influence meaningful organizational outcomes and prosper in their personal and professional lives as well. These results provide support 
for a proposed linkage between psychological empowerment and organizational identification. Taken together, the above arguments suggest:

Hypothesis 4: Psychological empowerment mediates the relationship between active transactional leadership and followers' organizational identification.

Comparing the Influences of Transformational versus Active Transactional Leadership

The main orientation of transformational leadership is to develop followers' full potential into leaders, but transactional leaders focus more on resource exchanges and on monitoring and controlling employees through rational or economic means (Bass, 2008). Therefore, we expect that transformational leadership would have a more positive effect on followers' organizational identification and psychological empowerment than transactional leadership.

Theoretically, transactional leadership is purported to be a less effective form of leadership than transformational leadership (Bass, 1985). Transactional leaders are considered to concentrate on compromise, intrigue, and control; therefore they are more likely to be seen as more inflexible, detached, and manipulative than transformational leaders (Bass \& Riggio, 2006). Empirically, prior research has indicated that transformational leadership has a more positive effect on many leadership outcomes, such as work attitudes and performance (e.g., Judge \& Piccolo, 2004; Lowe et al., 1996; Wang, Oh, Courtright, \& Colbert, 2011). For example, one meta-analysis (Lowe et al., 1996) showed that the correlations between transformational leadership and follower work attitudes and outcomes ranged from .60 to .71 , but those correlations for transactional leadership, including contingent reward, are below .41. Moreover, several prior reviews of the literature (c.f., Bass, 2008; Yukl, 2010) indicate that transformational leadership augments the positive influence of transactional leadership by explaining additional variance in followers' attitudes and performance. These results suggest that transformational leadership will explain variance in followers' psychological empowerment and organizational identification above and beyond variance explained by active transactional leadership. Our last two hypotheses are formally stated as:

Hypothesis 5: Transformational leadership explains additional variance in followers' psychological empowerment above and beyond active transactional leadership.

Hypothesis 6: Transformational leadership explains more variance in followers' organizational identification above and beyond active transactional leadership.

\section{Methodology}

\section{Sample and Data Collection}

We issued an internet-based survey through a research company, Zoomerang, which claims to possess the largest on-line research subject sample in the United States. This 
company has access not only to a nationally representative sample of the American population, but also to a huge sample pool of over 2.5 million research participants who have been pre-profiled on a variety of statistical variables, including demographic, industry, and occupational attributes. This online sample has been built and utilized widely to accomplish a broad range of research purposes, including market share estimation, business competiveness analysis, channel analysis, and political opinion polls (http://www.zoomerang.com). Therefore, due to its diverse nature and broad usage, we believe that this sample panel would be a suitable sampling pool for the purpose of conducting organizational studies. For the specific purpose of this study, we requested the research company to target full-time employees who were in managerial positions across a variety of industries. On our behalf, the research company sent the on-line survey to 2, 200 participants randomly sampled from participants who were fulltime workers in organizations. All the participants had the chance to win shopping coupons from the research company.

Our final sample includes 375 men and 297 women (a 30.55\% response rate among those solicited specifically for our survey) who were asked to make ratings of their supervisor's leadership and their own psychological empowerment and organizational identification. The response rate of $30.55 \%$ for this study was not significantly different $(Z$ score $=0.55)$ from the mean response rate of $38.9 \%(S D=15.1 \%)$ reported by Baruch and Holtom (2008), for online survey research. The average participant was 47.74 years old $(S D=10.82)$ and most $(70 \%)$ had a four-year college degree or higher. Participants in the final sample indicated that they had knowledge regarding their manager in terms of his/her span of control and job history through either personal knowledge or working relationships. Leaders rated by the participants supervised an average of 20.51 ( $S D=51.21$ ) followers and had been in their current position for an average of 9.80 years $(S D=8.68)$. Over $70 \%$ of leaders rated were upper-middle and top executives. More than 13 different industries were represented in the sample, from sectors including retail/wholesale (23\%), banking (13\%), information technology (13\%), and manufacturing (12\%).

\section{$\underline{\text { Measures }}$}

Transformational/transactional leadership. According to generally-accepted contemporary approaches to organizational behavior research (e.g., Klein, Dansereau, \& Hall, 1994; Yammarino \& Mumford, 2011), the nomological network of constructs examined in a study should be driven by theory, not a particular measurement instrument. As such, we built upon Ashford et al.'s (2008) model of identification and self-concept-based theories of transformational leadership (e.g., Shamir et al., 1993; Sosik \& Cameron, 2010) which suggest that active forms of leadership would arouse followers' self-concepts and promote organizational identification processes. To achieve data-theory alignment (Dansereau, Alutto, \& Yammarino, 1984), we used measures of transformational leadership and active forms of transactional leadership to tap into their respective constructs. Prior research has distinguished between the active and passive forms of transactional leadership, thus providing a precedent to separate contingent reward and active management-by-exception leadership from passive management-by- 
exception and laissez faire leadership (Avolio, Bass, \& Jung, 1999; Bycio et al., 1995; Sosik, 2006; Sosik \& Jung, 2010).

Transformational and transactional leadership actions/behaviors were evaluated by 28 items from the Multifactor Leadership Questionnaire (Bass \& Avolio, 1997). Respondents indicated whether they agreed with the statements on a 5-point scale ranging from 1 (strongly disagree) to 5 (strongly agree). Subscales included the following: idealized influence (8 items), intellectual stimulation (4 items), inspirational motivation (4 items), individualized consideration (4 items); contingent reward (4 items), and active management-by-exception (4 items). A sample item of intellectual stimulation was: "My leader re-examines critical assumptions to question whether they are appropriate." A sample item of contingent reward was: "My leader discusses in specific terms who is responsible for achieving performance targets."

Following a number of prior studies (e.g., Bono \& Judge, 2003), we averaged the first four dimensions to form an overall transformational leadership composite score $($ Cronbach alpha $=.96)$. A second order confirmatory factor analysis $(C F A)$ revealed that the model fits well with the data $\left(X^{2}=1051.76, p<.01, \mathrm{CFI}=.93, \mathrm{TFI}=.91\right.$, RMSEA $=.09$, SRMR $=.04$ ). Similarly, we aggregated the contingent reward and active management-by-exception into a combined factor of active transactional leadership $($ Cronbach alpha $=.70)$. A second order confirmatory factor analysis $(C F A)$ revealed that this model also fits well with the data $\left(X^{2}=2365.53, p<.01, \mathrm{CFI}=.90, \mathrm{TFI}=.90\right.$, RMSEA $=.09$, SRMR $=.06$ ).

Psychological empowerment. We used a 12-item scale to measure self-reported psychological empowerment (Spreitzer, 1995). Items were anchored by a 5-point scale ranging from 1 (strongly disagree) to 5 (strongly agree). Sample items for each of the four subscales include the following: "I am confident about my ability to do my job" (competence), "The work I do is very important to me" (meaning), "I can decide on my own how to go about doing my work" (self-determination), and "My impact on what happens in my department is large" (impact). Due to the fact that these four dimensions have relatively high inter-correlations (ranging from .54 to .74), we averaged the four dimensions to form an overall index of psychological empowerment (Cronbach alpha $=$ .93), which is consistent with the strategy adopted by Spreitzer (1995). CFA results showed that the model fits well with the data $\left(X^{2}=289.30, p<.01, \mathrm{CFI}=.96, \mathrm{TFI}=.95\right.$, RMSEA $=.08$, SRMR $=.04$ ).

Organizational identification. We used a 5-item scale to measure self-report organizational identification (Smidts, Pruyn, \& van Riel, 2001). Items were anchored by a 5-point scale ranging from 1 (strongly disagree) to 5 (strongly agree). A sample item is: "I feel strong ties with my organization." All five items were aggregated to represent an overall score for this construct (Cronbach alpha $=.95)$. Confirmatory factor analysis (CFA) results indicated that the data fits the model well $\left(X^{2}=227.77, p<.01, \mathrm{CFI}=.94\right.$, $\mathrm{TFI}=.89$, RMSEA $=.25$, SRMR $=.03$ ). Though RMSEA is higher than the cut-off score (Hu \& Bentler, 1999), the loading values of the five items on a one-dimensional factor are all over .70. Therefore, we concluded this scale is appropriate to be utilized in the study. 
Control variables. In this study, we included age, gender, education, income, leader organizational level, years of leadership experience, and years in current position as control variables in order to reduce the possible confounding effects of these variables. Regarding age, tenure, and years in current position, Carmeli, Atwater, and Levi (2011) argued that older employees who have been with an organization longer are more likely to have developed a higher quality of relationships with leaders, and therefore rate them more favorably. Regarding organizational level of the manager, a meta-analysis conducted by Lowe et al. (1996) reported that leaders at higher organizational levels are rated as more transformational, while lower level leaders are more likely to be rated as more transactional. Regarding gender, a meta-analysis conducted by Eagly, Johannesen-Schmidt, and Van Engen (2003) found that female leaders were rated more transformational than male leaders, and also engaged in more of the contingent reward behaviors, a component of transactional leadership. Male leaders are generally more likely to manifest other aspects of transactional leadership (i.e., active and passive management by exception). We also controlled for education level and income because these variables reflect socio-economic status which may affect leadership ratings (Bass, 2008; Yukl, 2010).

\section{Results}

The descriptive statistics and correlations for all study variables are shown in Table 1. Notably, transformational leadership had significant positive relationships with follower psychological empowerment $(r=.50, p<.01)$ and organizational identification $(r=.62, p<.01)$. Active transactional leadership had significant positive relationships with follower psychological empowerment $(r=.33, p<.01)$ and organizational identification

$(r=.69, p<.01)$. In addition, follower psychological empowerment was positively related to organizational identification $(r=.43, p<.01)$.

\section{Hypotheses Testing}

As shown in Table 2, all control variables (i.e., age, gender, education, the managerial level of participants, the managerial level of leaders rated, income level, leader's years in supervision position, leader's years in current supervision position, number of subordinates) were included in the regression analyses used to test the hypotheses.

Hypotheses 1 and 2 predicted that transformational and active transactional leadership would be positively associated with followers' organizational identification, respectively. As indicated in Step 2 of Table 2, transformational leadership was significantly and positively related to follower organizational identification $(\beta=.58, p<.01)$, thus providing support for Hypothesis 1 . As shown in Step 2 of Table 3, active transactional leadership was significantly and positively related to followers' organizational identification $(\beta=.41, p<.01)$, thus providing support for Hypothesis 2. 
Table 1

Descriptive Statistics and Correlations of Study Variables

\begin{tabular}{|c|c|c|c|c|c|c|c|c|c|c|c|c|c|c|}
\hline & Mean & $\overline{\mathrm{SD}}$ & 1 & 2 & 3 & 4 & 5 & 6 & 7 & 8 & 9 & 10 & 11 & 12 \\
\hline 1. Age & 47.74 & 10.83 & & & & & & & & & & & & \\
\hline 2. Gender & .44 & .50 & $-.23^{\star \star}$ & & & & & & & & & & & \\
\hline 3. Education & .63 & .48 & -.02 & $-.13^{\star \star}$ & & & & & & & & & & \\
\hline $\begin{array}{l}\text { 4. Managerial level } \\
\text { (self) }\end{array}$ & .38 & .49 & $.20^{* *}$ & $-.20^{\star *}$ & .07 & & & & & & & & & \\
\hline 5. Income & .28 & .45 & $.13^{\star *}$ & $-.17^{\star *}$ & $.22^{* *}$ & $.26^{\star *}$ & & & & & & & & \\
\hline $\begin{array}{l}\text { 6. Managerial level } \\
\text { (leader) }\end{array}$ & .73 & .45 & $.08^{*}$ & -.07 & .02 & $.38^{* *}$ & $.13^{\star \star}$ & & & & & & & \\
\hline $\begin{array}{l}\text { 7. Leader's years in } \\
\text { supervision position }\end{array}$ & 16.43 & 10.01 & $.28^{\star *}$ & $-.10^{\star \star}$ & -.02 & $.32^{\star \star}$ & $.12^{\star *}$ & $.32^{* *}$ & & & & & & \\
\hline $\begin{array}{l}\text { 8. Leader's years in } \\
\text { current supervision } \\
\text { position }\end{array}$ & 9.84 & 8.68 & $.20^{\star \star}$ & -.05 & $-.12^{\star *}$ & $.24^{\star *}$ & -.01 & $.20^{* *}$ & $.70^{\star *}$ & & & & & \\
\hline $\begin{array}{l}\text { 9. Number of } \\
\text { subordinates }\end{array}$ & 20.51 & 51.21 & .01 & -.05 & -.01 & .06 & .06 & .06 & .06 & .01 & & & & \\
\hline $\begin{array}{l}\text { 10. Transformational } \\
\text { leadership }\end{array}$ & 3.64 & .92 & .04 & -.04 & .02 & $.17^{\star *}$ & $.09^{*}$ & $.11^{\star *}$ & $.17^{\star \star}$ & $.14^{\star *}$ & -.03 & & & \\
\hline 11. Active trans. lead. & 3.34 & .70 & $.09^{*}$ & $-.11^{\star *}$ & .03 & $.13^{\star *}$ & $.11^{\star *}$ & .06 & $.14^{\star *}$ & $.17^{* *}$ & .06 & $.73^{\star \star}$ & & \\
\hline $\begin{array}{l}\text { 12. Psychological } \\
\text { empowerment }\end{array}$ & 4.24 & .67 & $.20^{* *}$ & .01 & $-.09^{*}$ & $.22^{* *}$ & $.09^{*}$ & $.18^{\star *}$ & $.16^{* *}$ & $.16^{\star \star}$ & -.04 & $.50^{\star *}$ & $.33^{* *}$ & \\
\hline 13. Org. identification & 3.91 & 1.04 & $.15^{\star \star}$ & -.03 & $-.10^{\star \star}$ & $.24^{\star \star}$ & $.11^{\star \star}$ & $.17^{\star \star}$ & $.21^{\star *}$ & $.19^{\star *}$ & -.05 & $.62^{* *}$ & $.69^{* *}$ & $.43^{\star \star}$ \\
\hline
\end{tabular}


Table 2

Mediation Tests (Transformational Leadership)

\begin{tabular}{|c|c|c|c|c|}
\hline & Step 1 & Step 2 & Step 3 & Step 4 \\
\hline & $\begin{array}{l}\text { Psychological } \\
\text { Empowerment }\end{array}$ & $\begin{array}{l}\text { Organizational } \\
\text { Identification }\end{array}$ & $\begin{array}{l}\text { Organizational } \\
\text { Identification }\end{array}$ & $\begin{array}{l}\text { Organizational } \\
\text { Identification }\end{array}$ \\
\hline Age & $.18^{\star \star}$ & $.10^{\star \star}$ & -.03 & .01 \\
\hline Gender & .06 & .03 & -.02 & -.01 \\
\hline Education & $-.10^{* *}$ & $-.12^{* *}$ & -.06 & $-.08^{*}$ \\
\hline Managerial level (self) & $.09^{*}$ & $.11^{\star *}$ & $.08^{*}$ & $.07^{\star}$ \\
\hline Income level & .03 & .04 & .03 & .02 \\
\hline Managerial level (leader) & $.08^{*}$ & .05 & .01 & .01 \\
\hline Leader's years in supervision position & -.04 & .04 & $.09^{\star}$ & .05 \\
\hline Leader's years in current supervision position & .04 & .01 & .01 & -.01 \\
\hline Number of subordinates & -.03 & -.05 & -.05 & -.04 \\
\hline Transformational leadership & $.47^{* *}$ & $.58^{\star \star}$ & & $.36^{\star \star}$ \\
\hline Psychological empowerment & & & $.66^{* *}$ & $.48^{* *}$ \\
\hline$R^{2}$ & .32 & .44 & .50 & .60 \\
\hline Adjusted $R^{2}$ & .31 & .43 & .49 & .59 \\
\hline$F(6,636)$ & $29.52^{* *}$ & $50.43^{* *}$ & $63.80^{\star *}$ & $85.25^{\star \star}$ \\
\hline
\end{tabular}

Note. $n=672,{ }^{*} p<.05{ }^{* *} p<.01$ 
Table 3

Mediation Tests (Active Transactional Leadership)

\begin{tabular}{|c|c|c|c|c|}
\hline & Step 1 & Step 2 & Step 3 & Step 4 \\
\hline & $\begin{array}{l}\text { Psychological } \\
\text { Empowerment }\end{array}$ & $\begin{array}{c}\text { Organizational } \\
\text { Identification }\end{array}$ & $\begin{array}{l}\text { Organizational } \\
\text { Identification }\end{array}$ & $\begin{array}{c}\text { Organizational } \\
\text { Identification }\end{array}$ \\
\hline Age & $.18^{* *}$ & $.10^{\star \star}$ & -.03 & -.01 \\
\hline Gender & .09 & .06 & -.02 & .01 \\
\hline Education & $-.10^{\star *}$ & $-.12^{\star *}$ & -.06 & $-.07^{*}$ \\
\hline Managerial level (self) & $.13^{\star}$ & $.15^{\star \star}$ & $.08^{*}$ & $.08^{*}$ \\
\hline Income level & .03 & .03 & .03 & .01 \\
\hline Managerial level (leader) & $.10^{*}$ & .07 & .01 & .01 \\
\hline Leader's years in supervision position & .01 & .09 & $.09^{*}$ & .01 \\
\hline Leader's years in current supervision position & .01 & -.02 & .01 & -.03 \\
\hline Number of subordinates & -.06 & $-.09^{*}$ & -.05 & $-.06^{*}$ \\
\hline Active transactional leadership & $.31^{* *}$ & $.41^{\star *}$ & & $.22^{\star *}$ \\
\hline Psychological empowerment & & & $.66^{\star *}$ & $.58^{\star \star}$ \\
\hline$R^{2}$ & $20^{\star *}$ & $.27^{\star *}$ & .50 & .55 \\
\hline Adjusted $R^{2}$ & $31^{\star *}$ & $.26^{\star \star}$ & .49 & .54 \\
\hline$F(10,636)$ & $15.91^{* *}$ & $23.91^{* *}$ & $63.80^{* *}$ & $68.77^{* *}$ \\
\hline
\end{tabular}

Note. $n=672,{ }^{*} p<.05{ }^{* *} p<.01$ 
We tested our mediation hypotheses following the four-step procedure recommended by Baron and Kenny (1986). Hypothesis 3 suggested that psychological empowerment would mediate the relationship between transformational leadership and follower organizational identification. Step 1 in Table 2 shows that transformational leadership is positively related to psychological empowerment $(\beta=.47, p<.01)$, thus satisfying the first condition. As indicated above, transformational leadership was related to follower organizational identification, thus condition 2 was met. As shown in Step 3 in Table 2, psychological empowerment was significantly related to follower organizational identification $(\beta=.66, p<.01)$, so the third condition was met.

As shown in Step 4 of Table 2, after psychological empowerment was added into the regression model, the initially significant relationship between transformational leadership and follower organizational identification $(\beta=.36, p<.01)$ was still significant. However, the Fisher $Z$ score value $(Z=5.22, p<.01)$ indicated that there was a significant difference between these two coefficients (.58 vs. .36). This showed that the relationship between transformational leadership and follower organizational identification was significantly reduced after psychological empowerment was added into the regression equation. Thus, follower psychological empowerment partially mediated the relationship between transformational leadership and followers' organizational identification, thus supporting our prediction in Hypothesis 3.

We conducted similar analyses to test the hypothesis that psychological empowerment mediated the relationship between active transactional leadership and follower organizational identification. As indicated in Step 2 of Table 3, active transactional leadership was significantly related to follower organizational identification $(\beta=.41, p<$ .01). As shown in Step 4 of Table 3, after psychological empowerment was added into the regression model, the initially significant relationship between active transactional leadership and follower organizational identification $(\beta=.22, p<.01)$ was still significant. However, the Fisher $Z$ score value $(Z=3.88, p<.01)$ indicated that there was a significant difference between these two coefficients (.41 vs. .22). Thus, follower psychological empowerment partially mediated the relationship between active transactional leadership and followers' organizational identification, thus supporting our prediction in Hypothesis 4.

We conducted a series of 3-step regression analyses to test the relative influence of transformational versus active transactional leadership on psychological empowerment (Hypothesis 5) and organizational identification (Hypothesis 6). Results of these analyses are summarized in Tables 4 and 5. 
Table 4

Test of the Augmentation Effect of Transformational Leadership over Active Transactional Leadership on Psychological Empowerment

\begin{tabular}{|c|c|c|}
\hline Steps/IVs & $\begin{array}{l}\text { Regression } \\
\text { coefficients }\end{array}$ & $\begin{array}{c}\mathrm{R}^{2} \\
\text { (Variance } \\
\text { explained) }\end{array}$ \\
\hline \multicolumn{3}{|l|}{ Model 1: } \\
\hline Step 1: Controls & & $.09^{* *}$ \\
\hline $\begin{array}{l}\text { Step 2: Adding } \\
\text { transformational leadership }\end{array}$ & $\mathrm{tfl}: .46^{\star \star}$ & $.29^{\star *}$ \\
\hline $\begin{array}{l}\text { Step 3: Adding active } \\
\text { transactional leadership }\end{array}$ & $\begin{array}{l}\text { tfl: } .51^{\star \star} \\
\text { tsl: }-.07\end{array}$ & $.29^{\star \star}$ \\
\hline \multicolumn{3}{|l|}{ Model 2: } \\
\hline Step 1: Controls & & $.10^{\star *}$ \\
\hline $\begin{array}{l}\text { Step 2: Adding active } \\
\text { transactional leadership }\end{array}$ & tsl: $.30^{\star \star}$ & $.17^{\star \star}$ \\
\hline $\begin{array}{l}\text { Step 3: Adding } \\
\text { transformational leadership }\end{array}$ & $\begin{array}{l}\text { tfl: } .51^{\star \star} \\
\text { tsl: }-.07\end{array}$ & $.29^{* *}$ \\
\hline
\end{tabular}

Table 5

Test of the Augmentation Effect of Transformational Leadership over Active Transactional Leadership on Organizational Identification

\begin{tabular}{|c|c|c|}
\hline Steps/IVs & $\begin{array}{l}\text { Regression } \\
\text { coefficients }\end{array}$ & $\begin{array}{c}\mathrm{R}^{2} \\
\text { (Variance } \\
\text { explained) }\end{array}$ \\
\hline \multicolumn{3}{|l|}{ Model 1: } \\
\hline Step 1: Controls & & $.10^{\star \star}$ \\
\hline $\begin{array}{l}\text { Step 2: Adding transformational } \\
\text { leadership }\end{array}$ & tfl: $.58^{* *}$ & $.42^{\star \star}$ \\
\hline $\begin{array}{l}\text { Step 3: Adding active } \\
\quad \text { transactional leadership }\end{array}$ & $\begin{array}{l}\text { tfl: } .62^{* *} \\
\text { tsl: }-.06\end{array}$ & $.42^{\star \star}$ \\
\hline \multicolumn{3}{|l|}{ Model 2: } \\
\hline Step 1: Controls & & $.10^{\star \star}$ \\
\hline $\begin{array}{l}\text { Step 2: Adding active } \\
\text { transactional leadership }\end{array}$ & tsl: $.40^{\star *}$ & $.24^{\star \star}$ \\
\hline $\begin{array}{l}\text { Step 3: Adding transformational } \\
\text { leadership }\end{array}$ & $\begin{array}{l}\text { tfl: } .62^{* *} \\
\text { tsl: }-.06\end{array}$ & $.42^{* *}$ \\
\hline
\end{tabular}

Note. IV = independent variables; tfl = transformational leadership; tsl $=$ active transactional leadership. ${ }^{* *} p<.01$ 
Regarding psychological empowerment, a review of Table 4 indicates that after adding active transactional leadership into the regression equation after transformational leadership, the explained variance in psychological empowerment is not increased. However, adding transformational leadership into the regression equation after active transactional leadership, the explained variance in psychological empowerment increases from .17 to .29 , indicating an augmentation effect of transformational leadership over active transactional leadership. Thus, Hypothesis 5 was supported.

Regarding organizational identification, a review of Table 5 indicates that after adding active transactional leadership into the regression equation after transformational leadership, the explained variance in organizational identification is not increased. However, adding transformational leadership into the regression equation after active transactional leadership, the explained variance in organizational identification increases from .24 to .42, indicating an augmentation effect of transformational leadership over active transactional leadership. Thus, Hypothesis 6 was also supported.

\section{Common Method Variance}

Though we were able to collect data with a diverse sample of participants from a broad spectrum of industries and organizations, we acknowledge that common method variance might be an issue that could affect our research findings, which is considered a methodological limitation of this study. Accordingly, we adopted a series of strategies recommended by some researchers (e.g., Podsakoff, MacKenzie, Lee, \& Podsakoff, 2003) to address this common method variance issue. First, we used Harman's 1-

Factor Test (Podsakoff et al., 2003) to examine the extent to which a common or singlemethod factor existed that would account for the variance in our findings. To accomplish this, we first performed an exploratory factor analysis (EFA) by entering all four scales used (i.e., transformational leadership, active transactional leadership, psychological empowerment, and organizational identification) in the survey study and results showed more than one factor emerged. The general one factor structure explained only $44.73 \%$ of the total variance, but 4 -factor structure explained $65.76 \%$ of the total variance, which indicated the latter model is superior to the earlier one.

Furthermore, we performed a CFA by including these four scales. Results showed that the goodness-of-fit indices of the hypothesized model (i.e., four separate factors) exhibited a much better fit to the data $\left(X^{2}=4032.42, d f=929, p<.01, \mathrm{CFI}=.90, \mathrm{TLI}=\right.$ .90 , RMSEA $=.07$; SRMR $=.05)$ than the one factor model $\left(X^{2}=11654.38, d f=945, p\right.$ $<.01, \mathrm{CFI}=.62, \mathrm{TLI}=.60, \mathrm{RMSEA}=.13, \mathrm{SRMR}=.12$ ), with all fitness indices far below the recommended level (Hu \& Bentler, 1999). This result showed that one common factor could not explain the research findings from this study. In sum, results of the above analyses provided evidence against the common method/source variance as an alternative explanation for the study results. However, we realize that it would be beneficial if future research could collect data from different sources to completely eliminate the confounding influence from same-source bias. 


\section{Discussion}

The central contribution of this research is that we have proposed and tested a theoretical model that adopts three established theoretical frameworks, including transformational leadership theory (Bass, 1985), organization identification theory (Ashforth et al., 2008; Smidts et al., 2001), and psychological empowerment theory (Spreitzer, 1995). While there has been an underlying assumption about the role of transformational leadership in identification processes, in this study we demonstrated how transformational leadership behaviors are associated with followers' organizational identification. Accordingly, we conclude that in order to manage followers' organizational identification, leaders need to promote followers' psychological empowerment.

While it is known that transformational leaders inspire followers (Inspirational Motivation), serve as positive role models (Idealized Influence), demonstrate individualized concern for followers (Individualized Consideration), and challenge them (Intellectual Stimulation), the results of this research suggest that transformational leaders may also empower followers. As such, results of this study provide further rationale and support for explaining how and why transformational leaders are effective. Yet, implicit in the conceptualizations of transformational leaders is the ability to "transform" followers into leaders (Bass, 1985; Burns, 1978). It seems relatively straightforward that follower psychological empowerment (Spreitzer, 1995) should and does play an important part in this transformation.

\section{Theoretical Implications}

This study has several theoretical implications for transformational leadership research. Specifically, this study borrows a perspective from work on psychological empowerment (Spreitzer, 1995), which encourages and strengthens our understanding of the influence dynamics of transformational leadership on followers (e.g., Shamir et al., 1993; Yukl, 2010), and suggests a broad conceptualization of transformational leadership theory. The primary contribution and implication of this study for both researchers and managers is to reinforce the value of transformational leadership (Bass, 1985; Burns, 1978).

Furthermore, we have begun to explore what has been referred to as the 'black box' (Jung \& Avolio, 2000) of how transformational leadership influences followers' organizational identification processes by demonstrating that feelings of psychological empowerment mediate the relationship between transformational leadership and followers' organizational identification. Though it has been previously argued that transformational leadership affects followers' organizational identification, this study has examined the underlying processes through which transformational leadership may affect follower organizational identification (Smidts et al., 2001), thereby extending existing research on transformational leadership. 
Furthermore, this study has made a contribution to the theoretical model proposed by Kark et al. (2003) in explaining the underlying influence mechanism through which transformational leadership affects followers' organizational identification, which has been discussed in their original model. Results indicate that our model is a plausible alternative model describing the influence mechanisms through which transformational leadership affects followers' organizational identification. We believe that future studies are necessary and needed to examine the dynamics and complexity of our proposed theoretical model and that proposed by Kark et al. (2003).

In addition, the research findings suggest that transformational leadership, compared to active transactional leadership, has a stronger positive relationship with followers' psychological empowerment and organizational identification. Not surprisingly, these findings, again, show that transformational leadership seems to be a superior and a more effective leadership style than transactional leadership (Bass, 1985), and add new evidence of the augmentation effect of transformational leadership over transactional leadership (Bass, 2008; Yukl, 2010). Moreover, these results were obtained from a survey research design that featured a sample consisting of a wide range of followers working in different leadership contexts, which suggests strong external validity or generalization of study results (Yammarino \& Mumford, 2011).

\section{Practical Implications}

There are several practical implications of the current research. First, by creating a greater sense of psychological empowerment, transformational leaders may have a more positive effect on levels of organizational identification among followers. To promote greater feelings of psychological empowerment, leaders should clearly articulate a vision that inspires followers to take greater responsibility for their work at all organizational levels. Goal clarification and a clear specification of tasks, roles and rewards perhaps, may also facilitate feelings of empowerment among employees, and then enhanced organizational identification consequently. Understanding employee needs, creating a supportive atmosphere, and engaging in confidence-building practices may also likely contribute to greater feelings of psychological empowerment (Spreitzer, 1995), which, in turn, may lead to higher levels of organizational identification among followers.

Another practical implication of this study is that we are able to propose some specific means to foster and develop follower organizational identification. One specific means is to develop transformational leadership across various organizational levels in order to develop follower identification with an organization. In practice, an organization could offer transformational leadership training (e.g., Bass \& Riggio, 2006; Sosik \& Jung, 2010 ) to their managers. These training programs and interventions can include key characteristics or behavioral dimensions of transformational leadership, namely, intellectual stimulation, individualized consideration, inspirational motivation, and idealized influence. For example, training programs can teach leaders to encourage and inspire their followers to develop more meaningful perceptions of their work. Such 
programs may also facilitate the open sharing of information, to enable followers to feel more empowered, and enhance their identification with the organization over time.

\section{Limitations, Future Research, and Conclusion}

We want to note a few important limitations to this research. The first limitation is the data is cross-sectional. Because our study is cross-sectional and not a longitudinal design, we acknowledge that a causal relationship between leadership, psychological empowerment, and follower organizational identification cannot be confirmed entirely by this study. We believe it would be beneficial for researchers to consider adopting a longitudinal field study or experimental research design to test psychological empowerment and organizational identification at different time periods to examine how these psychological dynamics develop over time. These approaches may help to cast more light on the dynamic complexity of leadership influence on these variables, and help draw the conclusion that the relationships are causal.

There appears to be some conceptual overlap between transformational leadership and psychological empowerment based on both constructs' focus on human development and continuous personal improvement (Bass, 1985; Spreitzer, 1995). Namely, transformational leadership focuses on the leader's efforts to increase followers' development, while psychological empowerment focuses on the followers' development and confidence. As such, an interesting question for future research is to examine why some people react positively to transformational leadership (i.e., link their self-identity to personal development) while others do not. This conceptual overlap may also influence the generally high degree of correlations among the study variables as shown in Table 1, which may explain the potential for common source bias as a limitation for this study, although results of both Harmon's 1-Factor Test and a series of CFAs indicated otherwise. As such, we suggest that future studies collect data on independent and dependent variables from different sources.

An additional limitation is that we did not include other important variables, such as value congruence between leader and followers (Jung \& Avolio, 2000), that could also be an important mediator of the relationship between transformational leadership and organizational identification. It is also possible that followers' value congruence with the organization (Fenton, \& Inglis, 2007) could be an important moderating variable that may strengthen the relationship between transformational leadership and followers' organizational identification. All of these research questions are worthy of further exploration in future studies.

One further limitation is that we did not measure objective indicators of followers' performance, which can be utilized to determine whether followers' psychological empowerment and organizational identification influences objective measures of followers' performance. Therefore, we suggest that future research testing our model adopts some objective and hard measures of performance. Such an approach would allow researchers to investigate the relationships proposed in this study in a more in- 
depth manner, and introduce more insightful understanding into the complex dynamics inherent in the theoretical model.

In conclusion, this study provides researchers investigating transformational leadership, psychological empowerment, and organizational identification with a preliminary map of how these constructs are related, and highlights the important challenges and responsibilities that are associated with transformational leadership research and practice. As indicated by several researchers (e.g., Bass \& Riggio, 2006; Sosik \& Jung, 2010), empowerment is a crucial process that defines transformational leadership and illustrates why it is effective in building follower organizational identification and performance. Followers' identification with the organization may be extremely important for their work attitudes, such as organizational commitment, and for other work performance measures, associated with excellence in the contemporary global marketplace.

\section{References}

Ashforth, B. E., Harrison, S. H., \& Corley, K. G. (2008). Identification in organizations: An examination of four fundamental questions. Journal of Management, 34(3), 325-374.

Ashforth, B. E., \& Mael, F. (1989). Social identity theory and the organization. Academy of Management Review, 14(1), 20-39.

Avolio, B. J. (1999). Full leadership development: Building the vital forces in organization. Thousand Oaks, CA: Sage Publications.

Avolio, B., J., Bass, B. M., \& Jung, D. I. (1999). Re-examining the components of transformational and transactional leadership using the Multifactor Leadership Questionnaire. Journal of Occupational and Organizational Psychology, 72, 441462.

Avolio, B. J., Bass, B. M., Walumbwa, F. O., \& Zhu, W. (2004). MLQ Multifactor Leadership Questionnaire (3rd Ed.). Redwood, CA: Mind Garden.

Avolio, B. J., Zhu, W., Koh, W., \& Bhatia, P. (2004). Transformational leadership and organizational commitment: mediating role of psychological empowerment and moderating role of structural distance. Journal of Organizational Behavior, 25, 951-968.

Baron, R. M., \& Kenny, D. A. (1986). The moderator-mediator variable distinction in social psychological research: Conceptual, strategic, and statistical considerations. Journal of Personality and Social Psychology, 51, 1173-1182.

Baruch, Y. \& Holtom, B. (2008). Survey response rate levels and trends in organizational research. Human Relations, 61(8), 1139-1160.

Bass, B. M. (1985). Leadership and performance beyond expectations. New York, NY: Free Press.

Bass, B. M. (2008). The Bass handbook of leadership: Theory, research and managerial applications ( $4^{\text {th }}$ ed.). New York, NY: Free Press.

Bass, B. M., \& Avolio, B. J. (1997). Full range of leadership: Manual for the Multi-factor Leadership Questionnaire. Palto Alto, CA: Mind Garden. 
Bass, B. M., \& Riggio, R. (2006). Transformational leadership( $2^{\text {nd }}$ ed.), Mahwah, NJ: Lawrence Erlbaum.

Bono, J., \& Judge, T. (2003). Self-concordance at work: Toward understanding the motivational effects of transformational leadership. Academy of Management Journal, 46, 554-571.

Burns, J. M. (1978). Leadership. New York, NY: Free Press.

Bycio, P., Hackett, R. D., \& Allen, J. S. (1995). Further assessments of Bass's (1985) conceptualization of transactional and transformational leadership. Journal of Applied Psychology, 80, 468-478.

Carmeli, A., Atwater, L., \& Levi, A. (2011). How leadership enhances employees' knowledge sharing: the intervening roles of relational and organizational identification. Journal of Technology Transfer, 36(3), 257-274.

Dansereau, F., Alutto, J. A., \& Yammarino, F. J. (1984). Theory testing in organizational behavior: The varient approach. Englewood Cliffs, NJ: Prentice-Hall.

Eagly, A.H., Johannesen-Schmidt, M.C., \& van Engen, M.L. (2003). Transformational, transactional, and laissez-faire leadership styles: A meta-analysis comparing men and women. Psychological Bulletin, 129, 569-591.

Epitropaki, O., \& Martin, T. (2005). The moderating role of individual differences in the relation between transformational/transactional leadership perceptions and organizational identification, The Leadership Quarterly, 16(4), 569-589.

Erturk, A. (2010). Exploring predictors of organizational identification: Moderating role of trust on the associations between empowerment, organizational support, and identification. European Journal of Work \& Organizational Psychology, 19(4), 409-441.

Fenton, N. E., \& Inglis, S. (2007). A critical perspective on organizational values. Nonprofit Management \& Leadership Journal, 17(3), 335-347.

Fulford, M. D. \& Enz, C. A. (1995). The impact of empowerment on service employees. Journal of Managerial Issues, 7, 161-175.

Fuller, J. B., Morrison, R., Jones, L., Bridger, D., \& Brown, V. (1999). The effects of psychological empowerment on transformational leadership and job satisfaction. Journal of Social Psychology, 139(3), 389-391.

Gkorezis, P., \& Petridou, E. (2008). Employees' psychological empowerment via intrinsic and extrinsic rewards. Academy of Healthcare Management Journal, 4(1), 17-39.

Hekman, D. R., Steensma, H. K., Bigley, G. A., Hereford, J. F. (2009). Effects of organizational and professional identification on the relationship between administrators' social influence and professional employees' adoption of new work behavior. Journal of Applied Psychology, 94(5), 1325-1335.

Hu, L., \& Bentler, P. M. (1999). Cutoff criteria for fit indexes in covariance structure analysis: Conventional criteria versus new alternatives. Structural Equation Modeling, 6(1), 1-55.

Johnson, S. K., \& Dipboye, R. L. (2008). Effects of charismatic content and delivery on follower task performance. Group \& Organization Management, 33(1), 77-106.

Judge, T. A., \& Piccolo, R. F. (2004). Transformational and transactional leadership: A meta-analytic test of their relative validity. Journal of Applied Psychology, 89, 755-768. 
Jung, D. I., \& Avolio, B. J. (2000). Opening the black box: An experimental investigation of the mediating effects of trust and value congruence on transformational and transactional leadership. Journal of Organizational Behavior, 21(8), 949-964.

Kark, R., \& Shamir, B. (2002). The dual effect of transformational and transactional leadership: priming relational and collective selves and further effects on followers. In Avolio, B., \& Yammarino, F. (2002), Transformational and charismatic leadership: The road ahead (pp. 67-91). Stamford, CT: JAI Press.

Kark, R., Shamir, B., \& Chen, G. (2003). The two faces of transformational leadership: Empowerment and dependency. Journal of Applied Psychology, 88(2), 246-255.

Klein, K., Dansereau, F. J., \& Hall, R. (1994). Levels issues in theory development, data collection, and analysis. Academy of Management Review, 19, 195- 229.

Koberg, C. S., Boss, R. W., Senjem, J. C., \& Goodman, E. A. (1999). Antecedents and outcomes of empowerment. Group \& Organization Management, 24(1), 71-90.

Liden, R. C., Wayne, S. J., \& Sparrow, R. T. (2000). An examination of the mediating role of psychological empowerment on the relations between the job, interpersonal relationships, and work outcomes. Journal of Applied Psychology, 85, 407-416.

Lowe, K. B., Kroeck, G. K., \& Sivasubramaniam, N. (1996). Effectiveness correlates of transformational and transactional leadership: A meta-analytic review of the MLQ literature. The Leadership Quarterly, 7, 385-425.

McCann, J. A. J., Langford, P. H., Rawlings, R. M. (2006). Testing Behling and McFillen's syncretical model of charismatic transformational leadership. Group \& Organization Management, 31(2), 237-263.

Meyer, J. P., \& Allen, N. J. (1991). A three-component conceptualization of organizational commitment. Human Resource Management Review, 1, 61-89.

Podsakoff, P.M., MacKenzie, S.B., Lee, J.L., \& Podsakoff, N.P. (2003). Common method biases in behavioral research: A critical review of the literature and recommended remedies. Journal of Applied Psychology, 88, 879-903.

Pratt, M. G. (1998). To be or not to be? Central questions in organizational identification. In D. A. Whetten \& P. C. Godfrey (Eds.), Identities in organizations: Building theory through conversations (pp.171-207). Thousand Oaks, CA: Sage.

Riketta, M. (2005). Organizational identification: A meta-analysis. Journal of Vocational Behavior, 66, 358-384.

Shamir, B., House, R. J., \& Arthur, M.B. (1993). The motivational effects of charismatic leadership: A self-concept theory. Organizational Science, 4(4), 577-594.

Shamir, B., Zakay, E., Breinin, E., Popper, M. (1998). Correlates of charismatic leader behavior in military units: Subordinates' attitudes, unit characteristics and superiors' appraisal of leader performance. Academy of Management Journal, 41, 387-409.

Smidts, A., Pruyn, A., \& Van Riel, C. B. M. (2001). The impact of employee communication and perceived external prestige on organizational identification. Academy of Management Journal, 44(5), 1051-1062.

Sosik, J. J. (2006). Full range leadership: Model, research, extensions and training. In C. Cooper \& R. Burke (Eds.) Inspiring leadership (pp. 33-66). New York, NY: Routledge. 
Sosik, J. J., \& Cameron, J. C. (2010). Character and authentic transformational leadership behavior: Expanding the ascetic self towards others. Consulting Psychology Journal: Practice and Research, 62(4), 251-269.

Sosik, J. J., \& Jung, D. I. (2010). Full range leadership development: Pathways for people, profit and planet. New York, NY: Routledge.

Spreitzer, G. M. (1995). Psychological empowerment in the workplace: Dimensions, measurement \& validation. Academy of Management Journal, 38, 1442-1465.

Taifel, H. (1972). Social categorization. In S. Moscovoci (Ed.), Introduction a la psychologie (Vol. 1), pp. 272-302). Paris: Larousse.

Tajfel, H., \& Turner, J. C. (1979). An integrative theory of inter-group conflict. In W. G. Austin \& S. Worchel (Eds.), The social psychology of inter-group relations (pp. 33-47). Monterey, CA: Brooks-Cole.

van Knippenberg, D., \& Sleebos, E. (2006). Organizational identification versus organizational commitment: Self-definitions, social exchange, and job attitudes. Journal of Organizational Behavior, 27, 585-605.

Wang, G., \& Lee, P. (2009). Psychological empowerment and job satisfaction: An analysis of interactive effects. Group \& Organization Management, 34(3), 271296.

Wang, G., Oh, I., Courtright, S. H., \& Colbert, A. E. (2011). Transformational leadership and performance across criteria and levels: A meta-analytic review of 25 years of research. Group \& Organization Management, 36(2), 223-270.

Yammarino, F. J., \& Mumford, M. D. (2011). Leadership and organizational politics: A multi-level review and framework of pragmatic deals. Politics in organizations: Theory and research considerations (SIOP Frontier Series). New York, NY: Taylor \& Francis.

Yukl, G. (2010). Leadership in organizations ( $7^{\text {th }}$ edition). Upper Saddle River, NJ: Prentice Hall.

Zhu, W., Riggio, R., Avolio, B. J., \& Sosik, J. J. (2011). The effect of leadership on follower moral identity: Does transformational/transactional style make a difference? Journal of Leadership and Organizational Studies, 18(2), 150 - 163. 